\title{
The Jesuits at Fort St. Joseph in Southwest Michigan
}

\author{
José António Brandão \\ Department of History, Western Michigan University, Kalamazoo, MI, USA \\ jose.brandao@wmich.edu \\ Michael S. Nassaney \\ Emeritus, Department of History, Western Michigan University, \\ Kalamazoo, MI, USA \\ nassaney@wmich.edu
}

\begin{abstract}
The site of Fort St. Joseph in southwest Michigan began as a mission in the 168 os when the Jesuits were granted a tract of land by the French crown along the St. Joseph River. For almost eighty years, the Jesuits tended to the souls of the Fort St. Joseph community. The presence of a marriage and baptismal register (1720-61) and archaeological remains testify to their religious activities in the eighteenth century. While it is difficult to measure Jesuit success at winning converts and the sincerity of the beliefs of both the French and Natives in their flock, documentary and material evidence inform on Jesuit practices. Catholicism endured among the denizens of the fort and was adopted by nearby Native peoples.
\end{abstract}

\section{Keywords}

French missions - Indian converts - Jesuits - New France - missionaries - devotional artifacts - religiosity - Fort St. Joseph

\section{Introduction}

As the French penetrated the interior of the continent, they often followed a missionary vanguard that also anticipated locations where French officials would construct permanent posts and settlements to advance their economic 
and military goals. One of those strategic places was along the St. Joseph River where the Jesuits established a field of missionary endeavor in the 168 os and where French colonial authorities ordered the construction in 1691 of what came to be known as Fort St. Joseph (Figure 1). To date, researchers have interrogated the Jesuit influence on the daily lives of the fort occupants and their Native allies to ascertain the sincerity of their beliefs. ${ }^{1}$ In this paper, we use new readings of documents and previously unanalyzed archaeological materials to gain a better understanding of the Jesuit presence at Fort St. Joseph and evaluate the outcomes of their efforts as they attracted converts, administered the sacraments, and preached to save souls. The evidence reveals Catholic conversions among Native peoples in the vicinity of the fort and the endurance of religious practices among the fort's occupants.

\section{The Jesuits in New France}

The Society of Jesus (better known as the Jesuits) was co-founded by the Basque nobleman Ignatius of Loyola (c.1491-1556), later canonized as St. Ignatius, and was officially recognized as a regular order of priests in 1540. By the mid-eighteenth century, there were three thousand Jesuits in France operating eighty-nine colleges (high schools) and thirty-two seminaries. ${ }^{2}$ As European powers expanded to Asia and then North America, so too did the Jesuit fields of endeavor. ${ }^{3}$ In New France, the Jesuits came mostly to inculcate and convert Native peoples into a new faith. By 1761 , at the fall of New France to the English, some 320 Jesuit priests and brothers had come to minister primarily to Natives and also to French colonists in the regions of the St. Lawrence, Great Lakes, and Louisiana. Almost two thirds of them arrived in the seventeenth century. ${ }^{4}$

1 José António Brandão and Michael S. Nassaney, "Suffering for Jesus: Penitential Practices at Fort St. Joseph (Niles, Michigan) during the French Regime," Catholic Historical Review 94, no. 3 (2008): 476-99; Dunning Idle, The Post of the St. Joseph River during the French Régime, 1679-1761 (Niles, MI: Support the Fort Inc., 2003), 31, 64, 87, 123; Joseph L. Peyser, ed., Letters from New France: The Upper Country, 1688-1783 (Urbana: University of Illinois Press, 1992), 24.

2 John O'Malley, S.J., "The Society of Jesus," in A Companion to the Reformation World, R. Po-chia Hsia, ed. (Oxford: Blackwell, 2004), 223-36, here, 223, 224.

3 The scope of French missionary efforts in the seventeenth century and its animating impulses are admirably laid out in Dominique Deslandres, Croire et faire croire: Les missions françaises au XVII e siècle (Paris: Fayard, 2003). See also her "French Catholicism in the Era of Exploration and Colonization," in Stephen J. Stein, ed., The Cambridge History of Religions in America, 3 vols. (Cambridge: Cambridge University Press, 2012), 1:200-18.

4 Reuben Gold Thwaites, ed., The Jesuit Relations and Allied Documents, 1610-1791, 73 vols. (Cleveland: Burrows Bros., 1896-19o1), 71:127-81. 


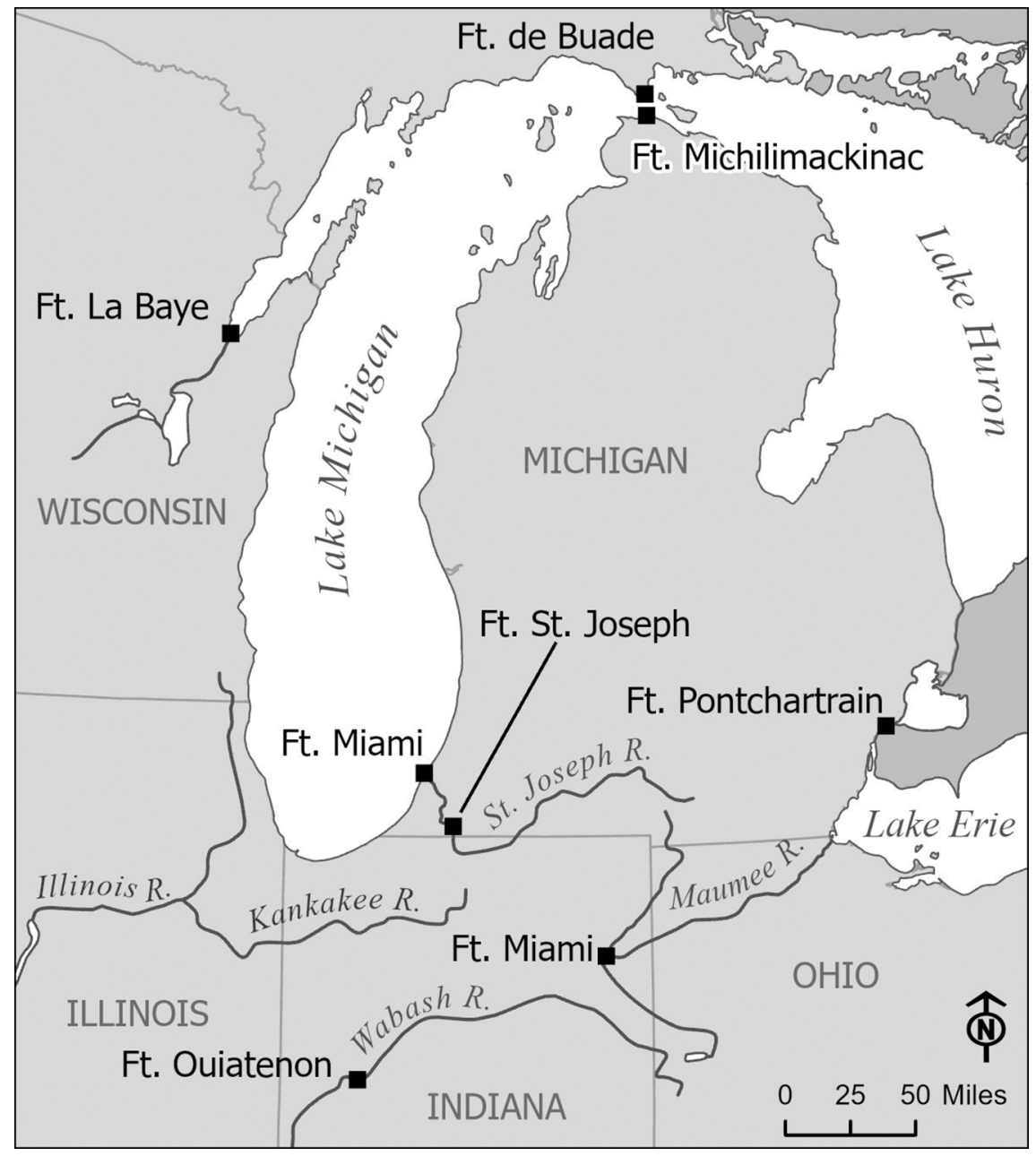

FIGURE 1 Location of Fort St. Joseph in relation to other French colonial sites in the western Great Lakes region

MAP BY JASON GLATZ

Sustained Jesuit activity and dominance in missionary work began after 1632. By 1640, there were forty Jesuits working in New France, where there was a nascent institutional church, but no bishop or formal parishes. ${ }^{5}$ Indeed, this was not surprising since "the main reason for the existence of an ecclesiastical organization in Canada was the salvation of the Indians and not the spiritual

5 William J. Eccles, "The Role of the Church in New France," in William J. Eccles, Essays on New France (Toronto: Oxford University Press, 1987), 26-37. 
well-being of the population of European origin."6 Still, even when formal parishes were established, most religious work administering the sacraments in the churches of Quebec, Montreal, and Three Rivers, was carried out by members of "the Society of Jesus (a regular order) and the Société de Saint-Sulpice (a congregation of secular priests)."7 The Jesuits further contributed to the religious and social welfare of settlers by, among other things, establishing a college in 1635 and by supporting charity through work with organizations of women religious who established hospitals and schools. ${ }^{8}$ The Jesuits were, from the start, integral to the religious life of the colony and their efforts were supported by the French crown (up to 25,00o livres annually) and by gifts from French patrons. ${ }^{9}$ The struggle to fund their work became more difficult after 1673 when the Jesuits stopped publishing their annual reports (their main fund-raising instrument), donor interests in France turned elsewhere, and internal squabbles erupted among the order's members about the mission's direction. Still, their contributions to the Catholic life of New France endured past the suppression of the order in France and New France, and the colony's demise. ${ }^{10}$

Jesuits in New France adapted their methods to the cultures of the groups they met, the political and economic circumstances of the day, and the number of missionaries available at the time they encountered and ministered to a particular group. Historian James Axtell has comprehensively fleshed out those methods." ${ }^{11}$ The Jesuits sometimes followed mobile hunter-gatherers while other times they went to live among horticulturalists. In mission fields at great distances from their base at Quebec, they often established a base of operation in a region that might include a church and a residence for priests to occupy after visiting Native groups in that region. ${ }^{12}$ Closer to home they

6 Luca Codignola, "French Catholicism in New France [168os-173os]," personal communication to Brandão, July, 2019. A shorter version of this essay was published as Luca Codignola, "French Catholicism in New France," in Stein, Cambridge History of Religions in America, 1:263-81. See also Luca Codignola, "The Historiography on the Jesuits of New France," in Jesuit Historiography Online, ed. Robert A. Maryks, doi:10.1163/2468-7723_jho_COM_22O17O (accessed January 16, 2021).

7 Codignola, "French Catholicism in New France," in Stein, Cambridge History of Religions in America, 264 .

8 O'Malley, "Society of Jesus," 232; Bronwen McShea, Apostles of Empire: The Jesuits in New France (Lincoln: University of Nebraska Press, 2019), 95-124.

9 Cornelius J. Jaenen, The Role of the Church in New France (Toronto: McGraw-Hill Ryerson, 1976), 70, 72; McShea, Apostles of Empire, 100-101.

10 McShea, Apostles of Empire, 194, 223-53.

11 James Axtell, The Invasion Within: The Contest of Cultures in Colonial North America (New York: Oxford University Press, 1985), especially 23-127, 271-86.

12 Examples include Sainte-Marie among the Hurons, the similarly named mission among the Iroquois, and the St. Ignace mission based at Michilimackinac and which served as the base of operation for the Great Lakes region, including Fort St. Joseph. 
operated reserves for neophytes and prospective converts, which served as a means to isolate them from the "contaminating" influences of French and non-Christian Natives. When in Native communities, Jesuits learned the local language, lived among those they sought to convert, and practiced a variety of methods to gain adherents. They sought to undermine Indigenous religious practitioners and prove, through the use of reason, technology, and mastery of science, that their God had imbued them with greater power than the "charlatan" who claimed to be able to cure them or to commune with spirits. Jesuits focused upon teaching the tenets of Catholicism and did not seek to alter those aspects of Native culture that did not contradict Catholic dogma. For the purposes of this paper, the most salient aspects of their work was their reliance, to make their case for conversion, on material culture items including crosses, crucifixes, and religious medallions with images of the holy family, various saints, and aspects of Catholic doctrine such as the crucifixion, the Eucharist, the annunciation, and the assumption..$^{13}$ Specially commissioned pictures and paintings, again illustrating central tenets of the faith (e.g., heaven, hell, the life of Jesus, etc.), were also vital to their methods. ${ }^{14}$

\section{The St. Joseph River Valley and the Jesuits}

The French were familiar with the St. Joseph River (then known as the "River of the Miamis") by the early 1680s due to the importance of the location for trade and for access to a large population of souls to convert. The Miami Indians had moved into southwest Michigan in the 168os, possibly accompanied by the Jesuit missionary Claude Allouez (1622-89). ${ }^{15}$ In 1695, some two hundred Potawatomis relocated to the River of the Miamis, and soon became the dominant force in the valley. ${ }^{16}$ The precise locations and the nature and

13 Axtell, Invasion within, 23-127, 271-86. François-Marc Gagnon, La conversion par l'image: Un aspect de la mission des jésuites auprès des Indiens du Canada (Montreal: Les Éditions Bellarmin, 1975), offers an extended and nuanced discussion of the Jesuit use of imagery and artifacts and Native perceptions and understanding of the latter, and the efficacy of the method. The Jesuits, he concludes, sought, and to some extent, managed to add to Native images and concepts Christian ones, even if not always as the Jesuits intended. Gagnon, $L a$ conversion par l'image, 14, 102-4.

14 Gagnon, La conversion par l'image.

15 Robert C. Myers and Joseph L. Peyser, "Four Flags over Fort St. Joseph," Michigan History Magazine 75, no. 5 (1991): 11-21, here 12.

16 Michael S. Nassaney, William M. Cremin, and LisaMarie Malischke, "Native AmericanFrench Interactions in Eighteenth-Century Southwest Michigan: The View from Fort St. Joseph," in Contested Territories: Native Americans and Non-Natives in the Lower Great Lakes, 
degree of interactions among these related Algonquian groups remain poorly understood.

By 1686, the Jesuits had been granted land for a house and chapel along the river, and by 1691 a trading post was ordered built near the present-day southern boundary of Niles, Michigan. ${ }^{17}$ The fort contained a small commander's house, a small garrison, and some buildings used to store trade goods and furs. ${ }^{18}$ There were no bastions, but a palisade of suspect quality existed. ${ }^{19}$ In 1753 , the post contained "fifteen huts which the owners call houses." ${ }^{20}$ The total population at the fort included the garrison, which, in the mid-1720s, included at most twenty men. ${ }^{21}$ By 1730 , there may have been as many as thirty families living around the fort, and by 1750 forty families were there-as many as one hundred men including blacksmiths, traders, soldiers, and engagés during the height of the summer before the traders returned to their various points of

1700-1850, ed. Charles Medina-Beatty and Melissa Rinehart (East Lansing: Michigan State University Press, 2012), 55-79, here 6o.

17 Peyser, Letters from New France, 43-44; Frontenac au Ministre, October 20, 1691, Rapport de l'Archiviste de la Province de Québec, 1927-1928, 69; José António Brandão "Your fyre shall burn no more": Iroquois Policy Towards New France and Its Native Allies to 1701 (Lincoln: University of Nebraska Press, 1997): 117-31; William J. Eccles, Frontenac: The Courtier Governor (Ottawa: Carlton Library Series, 1972): 273-94; Robert C. Myers and Joseph L. Peyser, "Four Flags over Fort St. Joseph," 11-21.

18 Gérard Malchelosse, "Le Poste de la Rivière Saint-Joseph (Mich.) (1691-1781)," Les Cahiers des dix 23 (1958): 139-86, here 144; Marthe Faribault-Beauregard La population des forts français d'Amérique (xviiie siècle), 2 vols. (Montreal: Éditions Bergeron, 1982 and 1984), 1:175.

19 "Extrait de la relation [de]... 1694 à 1695," in Pierre Margry, ed., Découvertes et établissements des Français dans l'ouest et dans le sud de l'Amérique septentrionale, 1614-1754, 6 vols. (Paris: D. Jouaust, 1876-86), 5:71; Pierre-François-Xavier Charlevoix, Histoire et description générale de la Nouvelle France avec le Journal Historique d'un Voyage fait par ordre du Roi dans l'Amérique Septentrionale, 3 vols. (Paris: Chez Rollin Fils, Librarie, Quai des Augustins, François Giffart) MDccXLIV [1744], 3:312; [Jacques-François Forget Duverger], "Rélation D’un voyage Intéressant au Canada [26 juin, 1753-22 novembre, 1754], in Variétés Philosophiques et Littéraires, Bibliothèque Universitaire de Rennes, Miscellanea, Tome VII, ms 213, fol. $79^{v}$; Anonymous, "Mémoire sur la partie occidentale du Canada, depuis Michillimakinac jusqu'au fleuve du Mississippi," in Bulletin des Recherches Historiques 26, no. 1 (janvier 1920): 25-32 and 26, no. 2 (février 1920): 56-64, here 56. Unless otherwise indicated, translations from French are by Brandão.

$20 \quad$ [Forget Duverger], "Relation," fol. 79 ; Malchelosse, "Le Poste de Saint-Joseph," 169.

21 Joseph L. Peyser, ed. and trans, Fort St. Joseph Manuscripts: Chronological Inventory of French Language Manuscripts and Their Translations (Niles, MI: Four Flags Historical Study Committee, 1978) document 44; Anon., "Mémoire sur la partie occidentale du Canada," 56. 
origins. ${ }^{22}$ The few eyewitnesses who comment on the size of the population indicate quite clearly that approximately a dozen French families, living in about fifteen houses, made the fort their home year round. ${ }^{23}$

We do not know if or where the Jesuits lived at the fort, if there was a chapel, and what these buildings would have looked like. In the mid-168os, and possibly starting as early as 1679, Allouez carried out missionary activities upriver from La Salle's post. ${ }^{24}$ A land grant was made to Claude Dablon (1619-97) and other Jesuit missionaries on October 1, 1686 for twenty arpents (seventeen acres) of land fronting on the St. Joseph River to build a chapel and a house and to sow grain and vegetables, in perpetuity. In 1689, King Louis XIV (r.1643-1715) confirmed the grant, which clearly reflected the fact that Allouez, at the least, had been working in the area and had found it a worthwhile location for a regular mission post with a periodic, if not year-round, missionary presence. ${ }^{25}$ As if to confirm that, when Allouez died in 1689, Claude Aveneau (1650-1711) was appointed to replace him. ${ }^{26}$ There is, however, no evidence that a location was chosen for the mission or that any supporting structures were built. References to the "mission" in these decades were most likely to a field of missionary activity, and not to actual buildings.

References to a built mission environment emerge following the construction of Fort St. Joseph after 169o. Almost all such references were made in conjunction with descriptions of the fort's built environment and suggest at best rudimentary mission construction. For example, Miamensa (dates unknown), speaking for the Miami Indians who made up part of the Fort St. Joseph community and were, at two 1702 conferences, being urged to relocate to Detroit, noted that their priest (at this point Father Aveneau) was encouraging them to stay put. Aveneau had told them that the governor, Philippe de Rigaud de

22 Malchelosse, "Le Post de Saint-Joseph," 15o. Malchelosse may have been counting French and Native households that formed each summer as traders returned to the area. These seasonal households may have lasted for the lifetimes of those in them.

23 Anon., "Mémoire sur la partie occidentale du Canada," 56; [Forget Duverger], "Relation," fol. $79^{\mathrm{v}}$; [Thomas Hutchins], "A Tour from Fort Cumberland North Westward round part of the Lake Erie, Huron and Michigan, including part of the Rivers St. Joseph, the Wabash, and Miamis, with a Sketch of the Road from thence by the Lower Shawanoe Town to Fort Pitt. [1]762."; Malchelosse, "Le Poste de Saint-Joseph," 161, 169.

24 George Paré, The Catholic Church in Detroit, 1701-1888 (Detroit: Wayne State University Press, 1983), 78-85. See also, Dunning Idle, The Post of the St. Joseph River, 5-6.

25 Margry, Découvertes et établissements, 5:35.

26 On Allouez's death, and the debate over where he died, see Paré, Catholic Church in Detroit, 83-84. On Aveneau's work at the St. Joseph mission, see Thwaites, Jesuit Relations, 66:213-15. Aveneau was assisted at the mission from about 1698 or 1699 to 1702 by Father Jean Mermet. Thwaites, Jesuit Relations, 339 and Paré, Catholic Church in Detroit, 86; Donald Chaput, "Mermet, Jean," in George Brown et al., eds., The Dictionary of Canadian Biography (Toronto: University of Toronto Press, 1966-), 2:468-69. 
Vaudreuil (1691-1763), promised he would build "houses and grand lodgings" for them. ${ }^{27}$ It is not clear whether that was a reference to mission structures or strengthening the fort, but the king had closed the fort and it would have been fool-hardy for Vaudreuil to promise to re-establish it. Moreover, a promise to support the Jesuit mission would have made sense and supported Vaudreuil's aim of hindering the development of Detroit without seeming to oppose the king's decrees.

Other equally fleeting references point to a Jesuit residence and chapel, but it is unclear whether they were located within the fort palisade or in an Indian village. In 1712, Gabriel Marest (1662-1727) reported meeting his brother Joseph (1653-1725) at the "Saint Joseph Mission to the Pouteautomis." Father Marest made no mention of the fort or any Jesuit structures in the Indian village. ${ }^{28} \mathrm{In}$ 1721, Pierre-François-Xavier Charlevoix (1682-1761) visited the area and noted his arrival "at this post where we have a mission." ${ }^{29} \mathrm{He}$ made no mention of a Jesuit residence or chapel in the fort but recounts an incident that suggests a house and chapel existed, perhaps in the Potawatomi village. Ouilamek (dates unknown), a "well-instructed Christian" who had become complacent in practicing his faith, was reproached by Charlevoix for his conduct. Ouilamek, apparently unhappy at this, took his abrupt leave, "went in the chapel, and said his prayers in a loud voice, such that we could understand him at the missionary's place." ${ }^{30}$ This suggests the existence of a chapel and Jesuit residence likely in or near the village. It would be too much to expect Ouilamek's voice to carry from the village to the fort, no matter how close they might have been to one another, and no source mentions a chapel in the fort. Father Jacques-François Forget Duverger ( $\left.f .1753^{-64}\right)$, a priest of the Séminaire des Missions Étrangères who visited Fort St. Joseph, mentioned being received by Father Jean-Baptiste de la Morinie (fl.1704-64) at his house in the context of describing the fort itself. But later in his journal he does not indicate the Jesuit lived in the fort when he enumerated the number of houses in it. ${ }^{31}$ The one clear reference to a Jesuit residence in the fort comes from a 1761 report by Dietrich Brehm in which he noted that there was no separate officer's house and that the commander had come to use "a Privat House, in which the Priest used to live."32 It seems possible to reconcile these apparent contradictions by suggesting that

27 Margry, Découvertes et établissements, 5:281, 283.

28 Thwaites, Jesuit Relations, 66:281-83.

29 Charlevoix, Histoire et description, 3:312.

30 Charlevoix, Histoire et description, 3:320.

$31 \quad$ Forget Duverger, "Relation," fol. $79^{\mathrm{v}}$.

32 "Dietrich Brehm's Report for the 1761 Expedition," in Keith R. Widder, Beyond Pontiac's Shadow: Michilimackinac and the Anglo-Indian War of 1763 (East Lansing and Mackinac 
living arrangements were not constant and that the Jesuits had no permanent residence there.

Finally, information in the Fort St. Joseph baptismal records point to the existence of a chapel in the decades after 1721. In July 1741, Marie Françoise (d.1741), a Panis, was baptized by Father Jean-Baptiste de la Morinie, died some days later, and was "buried in the church of this mission." 33 In April 1752, two more Native children were baptized in the "church of this mission." ${ }^{44}$ These are the lone references to a chapel at the mission, and as each refers to a Native Catholic event, it seems reasonable to conclude that the chapel was in an Indian village away from the fort. That conclusion is reinforced by the fact that no source mentions a chapel in the fort proper, the Jesuit missionary effort preceded the fort's construction, and the Jesuit presence in New France was to minister to Indians and only by way of duty and calling, to French settlers.

This then, was the mission field in which the Jesuits labored to bring Catholicism to French and Indian alike. What remains to be determined are the impacts of their efforts.

\section{The St. Joseph Baptismal Register}

Among the more significant documents pertaining to Jesuit activities at Fort St. Joseph is a "baptismal register" which lists some of the baptisms and marriages performed at the fort and notes those who died there. ${ }^{35}$ There are clearly gaps in the register, suggesting that it is incomplete. There are also no entries for the period from at least 1690 to 1721 when the fort and mission seem to have developed in tandem, and other sources reveal Jesuits were carrying out their missionary work there. It is not clear if the document was kept at the fort and entries made by missionaries when they visited, or if it accompanied the priest, who later entered events that took place at other times. It may also have been kept at Fort Michilimackinac, a center for missionary activities in

Island: Michigan State University Press and Mackinac State Historic Parks, 2013), 248-52, here 25 o.

33 George Paré and Milo Milton Quaife, eds., "The St. Joseph Baptismal Register," Mississippi Valley Historical Review 18, no. 2 (1926): 201-39, here 219.

34 Paré and Quaife, "St. Joseph Baptismal Register," 222, 223.

35 Two printed versions of the register exist. It is available in an English translation by George Paré and in French by Marthe Faribault-Beauregard. Both versions were used for this work. Paré translated each entry in its entirety and as it appears in the original while FaribaultBeauregard organized the register into categories of people (French, Indian, captives), event (marriage, baptism, death), and usually provides only the names of those involved in the event and the dates. 
the region, and entries added when the priests returned. There is no way to tell if there were contemporaneous entries, logged by others who may have had access to the register. This last option is unlikely, since few could write, and fewer still would have tampered with a church document. Given the hazards of canoe travel, it seems likely that the register remained at Fort St. Joseph, but there is no way to confirm this.

We have compiled data on religious activities in the St. Joseph mission in the hopes that the overview that emerges, added to the information in the register itself, will shed light on Jesuits activities at Fort St. Joseph (Table 1). The month, or months, listed for each missionary are based upon the dates when they entered some event in the register. In some cases, the month listed indicates multiple entries, and at other times a single entry. There is no clear way to determine if a single entry means that there was little activity to record or if the missionary was not there more than a day. It is equally impossible to ascertain if a number of entries over several months means the priest was at the mission the entire time. Entries made weeks apart may suggest little activity in the interval between entries, or perhaps that the missionary travelled out of the area.

The admittedly incomplete register allows several inferences. First, it is clear that missionaries were not continuously present at the fort. Not only were they not there every year, but when present, they did not stay long. Additionally, the practice of Catholicism mattered to the fort's inhabitants. For example, children born when a priest was absent were presented for baptism when the priest arrived. Also, children in ill health after birth were given a form of "emergency" christening, called a summary baptism, so that if they expired their souls would be saved and, if they survived, they could be presented for formal baptism when the priest arrived. In 1768, 1773, and 1775, after regular missionary visits to the fort had ended, denizens of the fort sought out priests in other locales to perform baptisms. The missionary Pierre Gibault (d.1802), based in the Illinois region, sometimes baptized children from St. Joseph years after they were born. This implies both the uncertainties of opportunity and availability of priests, and people's desire to persist in practicing their faith. The case of Pierre Mekabikanga ( $f$ l.1745-52), a Miami man, illustrates that this attachment to rituals of the Catholic Church was not limited to French settlers. Pierre was married twice in the "eyes of the Church" to Native women (his first wife died) and waited two years to baptize his daughter because no missionary was around at her birth. ${ }^{36}$ His marriages to Native women indicate that all

36 Paré, “The St. Joseph Baptismal Register," 222. 
TABLE 1 Jesuit missionaries at Fort St. Joseph listed in the baptismal register

\begin{tabular}{|c|c|c|}
\hline Year & Month(s) & Missionary \\
\hline \multirow[t]{2}{*}{1721} & January & Fr. Jean-Baptiste de Saint Pé \\
\hline & March-April & Fr. Michel Guignas \\
\hline 1722 & May-October & Fr. Jean-Charles Guymonneau \\
\hline 1723 & February & Fr. Guymonneau \\
\hline 1724 & September-December & Fr. Charles-Michel Mesaiger \\
\hline 1725 & May-August & Fr. Mesaiger \\
\hline 1726 & April-August & Fr. Mesaiger \\
\hline 1727 & May-September & Fr. Mesaiger \\
\hline 1728 & April & Fr. Mesaiger \\
\hline \multirow[t]{2}{*}{1729} & August & Fr. Jean-Baptiste Chardon \\
\hline & September-October & Fr. Mesaiger \\
\hline 1730 & June-November & Fr. Mesaiger \\
\hline 1731 & January & Fr. Mesaiger \\
\hline 1734 & September & Fr. Saint Pé \\
\hline 1735 & July-September & Fr. Jean-Louis de la Pierre \\
\hline 1738 & March-June & Fr. Pierre du Jaunay \\
\hline 1740 & January-April & Fr. Jean-Baptiste de la Morinie \\
\hline 1741 & June-July & Fr. la Morinie \\
\hline 1742 & March-April & Fr. du Jaunay \\
\hline 1743 & October & Fr. la Morinie \\
\hline 1744 & March-July & Fr. la Morinie \\
\hline 1745 & June & Fr. du Jaunay \\
\hline \multirow[t]{2}{*}{$175^{2}$} & April & Fr. la Morinie \\
\hline & April-May & Fr. du Jaunay \\
\hline 1753 & February-June & Fr. la Morinie \\
\hline 1754 & August & Fr. la Morinie \\
\hline 1755 & June-September & Fr. la Morinie \\
\hline $175^{6}$ & January-July & Fr. la Morinie \\
\hline 1757 & March-July & Fr. la Morinie \\
\hline $175^{8}$ & May-December & Fr. la Morinie \\
\hline 1759 & January-February & Fr. la Morinie \\
\hline 1760 & May-June & Fr. la Morinie \\
\hline 1761 & January, June & Fr. Pierre Potier* \\
\hline 1768 & July, August & [Fr.?]Pierre Gibault** \\
\hline 1773 & March & [Fr.?]Pierre Gibault ${ }^{* *}$ \\
\hline 1775 & January & [Fr.?]Pierre Gibault** \\
\hline
\end{tabular}

*Father Pierre Poiter performed baptisms on his way west of the fort and on return.

**[Father] Pierre Gubault is listed in the register as a missionary priest, but his actual title is currently uncertain. He baptized a number of Fort St. Joseph residents who travelled to see him in the Illinois region. The events were attributed to the FSJ mission, but were recorded in the register for Ste. Anne's Church in Detroit. 
three were in full communion with the church as it was only in such cases that Catholic marriages were sanctioned. ${ }^{37}$

The records also reveal that, whether by inclination or opportunity, some missionaries were clearly more active among the Indians than others. Mesaiger officiated, or noted in the register, more Indian baptisms and burials than any other at the fort, despite the fact that Father la Morinie was there much longer. In addition, despite the irregular priestly presence, Catholic practices endured. Over the approximately forty-year span for which there are records of the fort there were five recorded marriages: two between people who can be identified as French; one between a French man and an Indian woman; and those of Pierre Mekabikanga who, as noted above, married twice. This suggests also that some of the French came to the fort already married or married at other posts in the area. Baptisms included ninety-five children identified as French, five enslaved Indians (likely young adults or adults), and forty-one Native children. Four French people and thirteen Indians were recorded as having died at the fort - the latter were almost all children who died shortly after baptism.

In sum, Jesuits regularly administered the sacraments to members of the Fort St. Joseph community and had established a church or chapel as a focus of their mission.

\section{Archaeological Evidence of Religious Activity}

To reinforce their religious messages and to assist in conversion, the Jesuits often employed imagery in the form of statues, relics, paintings, and other religious paraphernalia to mediate human relationships with supernatural beings, much as Jesuits mediated relations between earthly and heavenly worlds. ${ }^{38}$ Religious objects are relatively rare but consistent finds on French and Spanish colonial sites in the Americas; Fort St. Joseph is no exception. Researchers have noted that the type, raw material, form, and iconography of religious objects can be used to infer chronology, associations with particular religious denominations, and their role in society. ${ }^{39}$ Here we examine some of the attributes

37 Luca Codignola, "The Issue of Tridentine Marriage in a Composite North Atlantic World: Doctrinal Strictures vs. Loose Practices, 1607-1738," Journal of Early American History 5 (2015): 201-70.

38 Laura E. Masur, "Priestly Plantations: An Archaeology of Capitalism and Community in British North America" (unpublished PhD diss., Boston University, 2019), 286.

39 Kathleen A. Deagan, Artifacts of the Spanish Colonies of Florida and the Caribbean, 1500-1800, vol. 2: Portable Personal Possessions (Washington, DC: Smithsonian Institution Press, 2002); Lynn L. M. Evans, "Artifacts of Religious Devotion at Michilimackinac," Le Journal: The 
and spatial distribution of devotional artifacts from Fort St. Joseph to determine their meanings and the sincerity of Catholic beliefs in the Fort St. Joseph community.

In this study we focus on crosses, crucifixes (Table 2), religious medallions (Table 3), and a cilice from Fort St. Joseph. ${ }^{40}$ Many of these objects were obtained by local collectors in the early twentieth century and are curated in regional museums $(\mathrm{n}=37)$, with the majority at the Fort St. Joseph Museum in Niles, Michigan.${ }^{41}$ While we cannot be certain that all of them are from the fort site, it is highly likely that they are from the vicinity of the fort and were associated with the Fort St. Joseph community. In addition to these objects, controlled excavations conducted at the fort since 1998 have led to the recovery of thirteen devotional artifacts (excluding rosary beads and iconographic rings). Here we describe the medallions, crosses, crucifixes, and a cilice to infer their role in proselytism and the piety of Catholic practitioners on the frontiers of New France.

All of the objects in this analysis are consistent with the types of religious paraphernalia recovered from contemporaneous North American sites (Tables 2 and 3). Most of them were imported from Europe, though they do not appear in any lists of goods that were intended to be traded at the fort. This may indicate that the Jesuits distributed these devotional artifacts to their religious followers. ${ }^{42}$ On the other hand, the presence of a limestone mold for producing lead crosses and what appear to be expediently produced crosses cut from sheet silver suggest that some items were locally made..$^{43}$ At Fort Michilimackinac, a concentration of crosses and medallions recovered from the area where the blacksmith worked supports an argument for some local production there. ${ }^{44}$

Quarterly Publication of the Center for French Colonial Studies 36, no. 1 (2020): 6-14; Masur, "Priestly Plantations"; Charles J. Rinehart, "Crucifixes and Medallions from Michilimackinac," in The Fur Trade Revisited: Selected Papers of the Sixth North American Fur Trade Conference, Mackinac Island, Michigan, 1991, ed., Jennifer S. H. Brown, William J. Eccles, and Donald P. Heldman (East Lansing: Michigan State University Press, 1994), 331-48; Timothy B. Riordan, "To Excite the Devotion of the Catholics": The Use and Meaning of Catholic Religious Medals in the Colonial Period," Historical Archaeology 49, no. 4 (2015): 71-86.

40 Brandão and Nassaney, "Suffering for Jesus," 476-99; Charles A. Hulse, "An Archaeological Evaluation of Fort St. Joseph: An Eighteenth-Century Military Post and Settlement in Berrien County, Michigan" (MA thesis, Michigan State University, 1977).

41 Not included in the analysis are some objects in the Kalamazoo Valley Museum and the History Museum in South Bend, Indiana, and some described by Charles Hulse, "Archaeological Evaluation of Fort St. Joseph." Andrew Beaupré, "Sacred or Secular: Religious Materiality on the French Colonial Frontier" (MA thesis, Western Michigan University, 2011).

43 Hulse, "Archaeological Evaluation of Fort St. Joseph," 172, 174

44 Rinehart, "Crucifixes and Medallions from Michilimackinac," 339. 


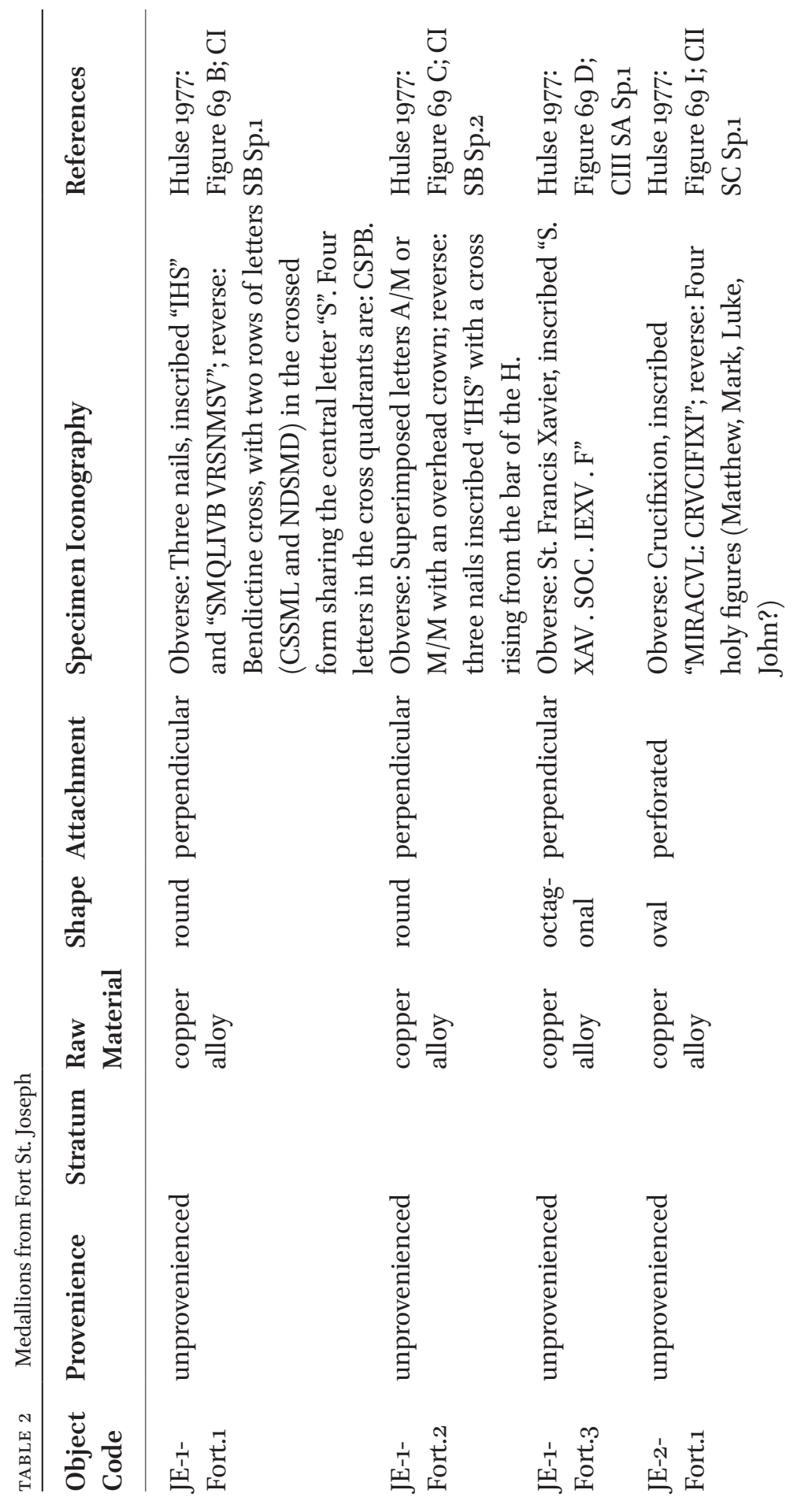




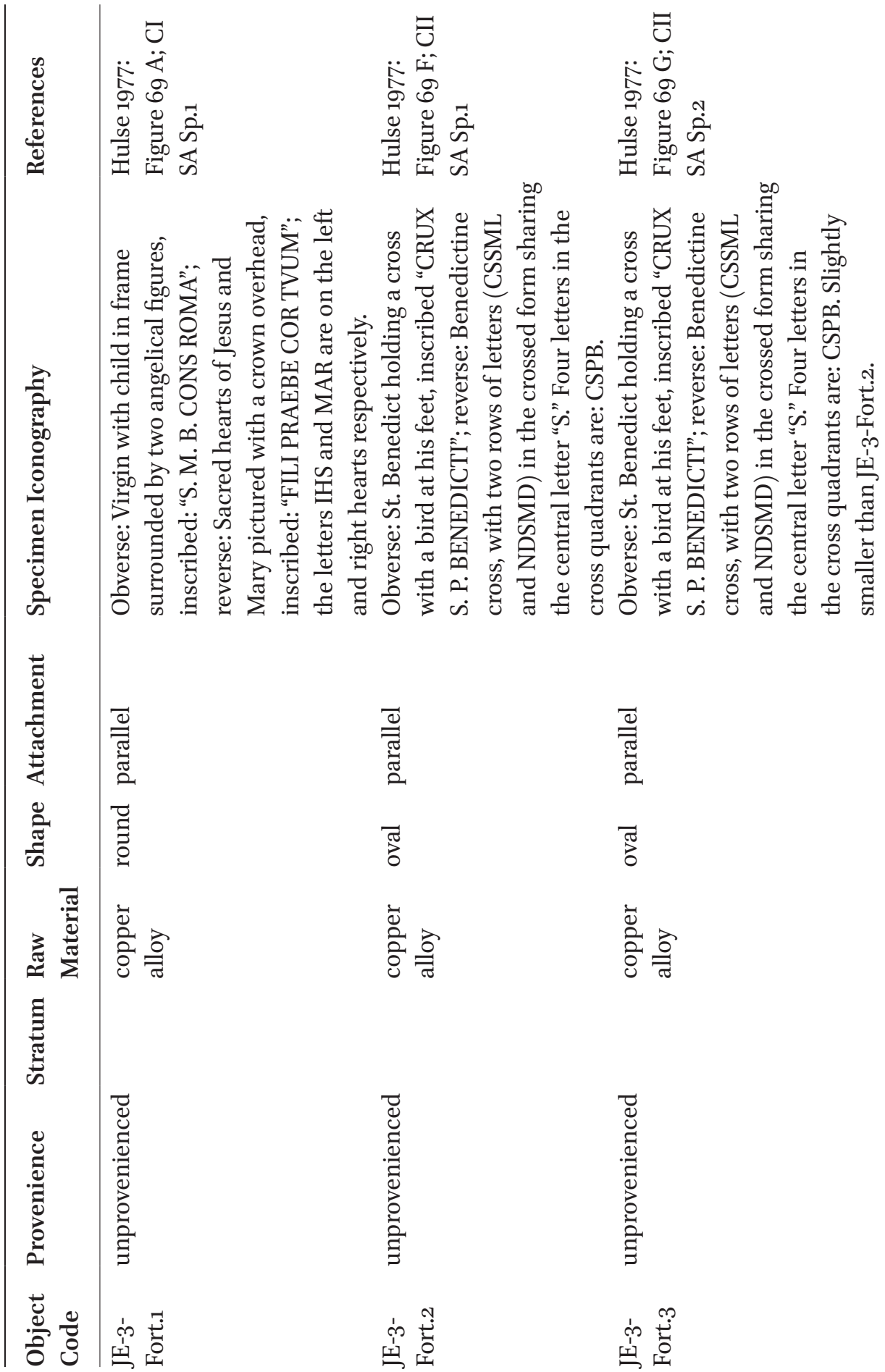




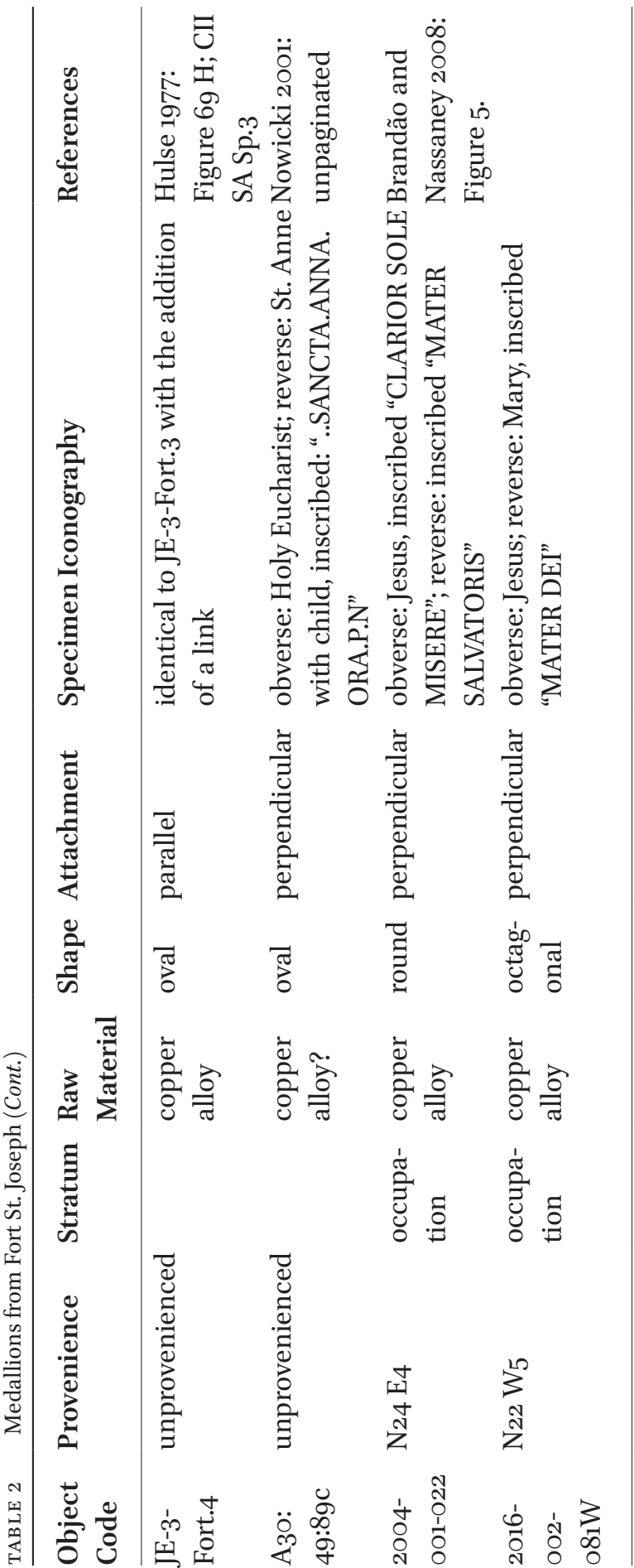




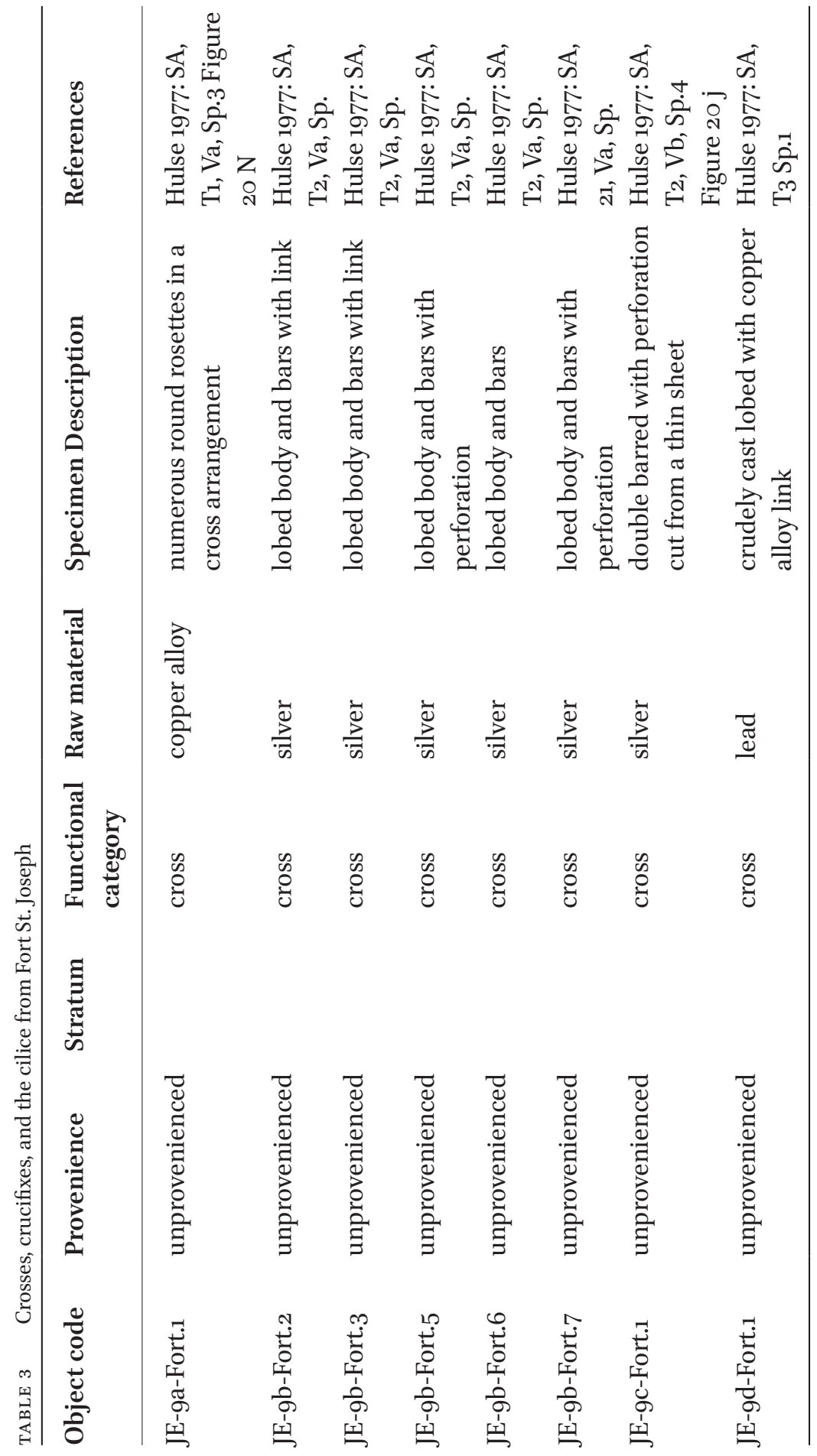




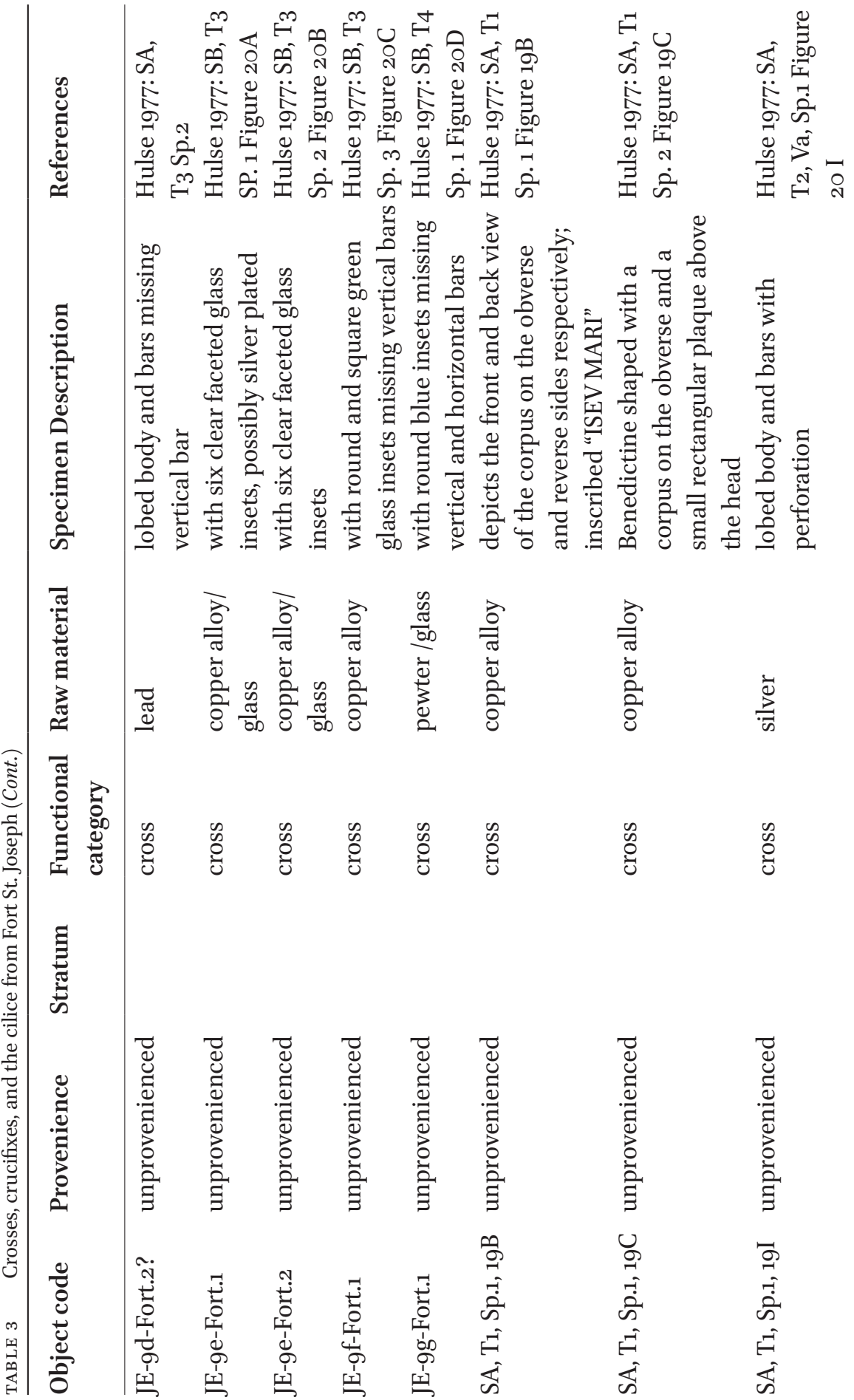




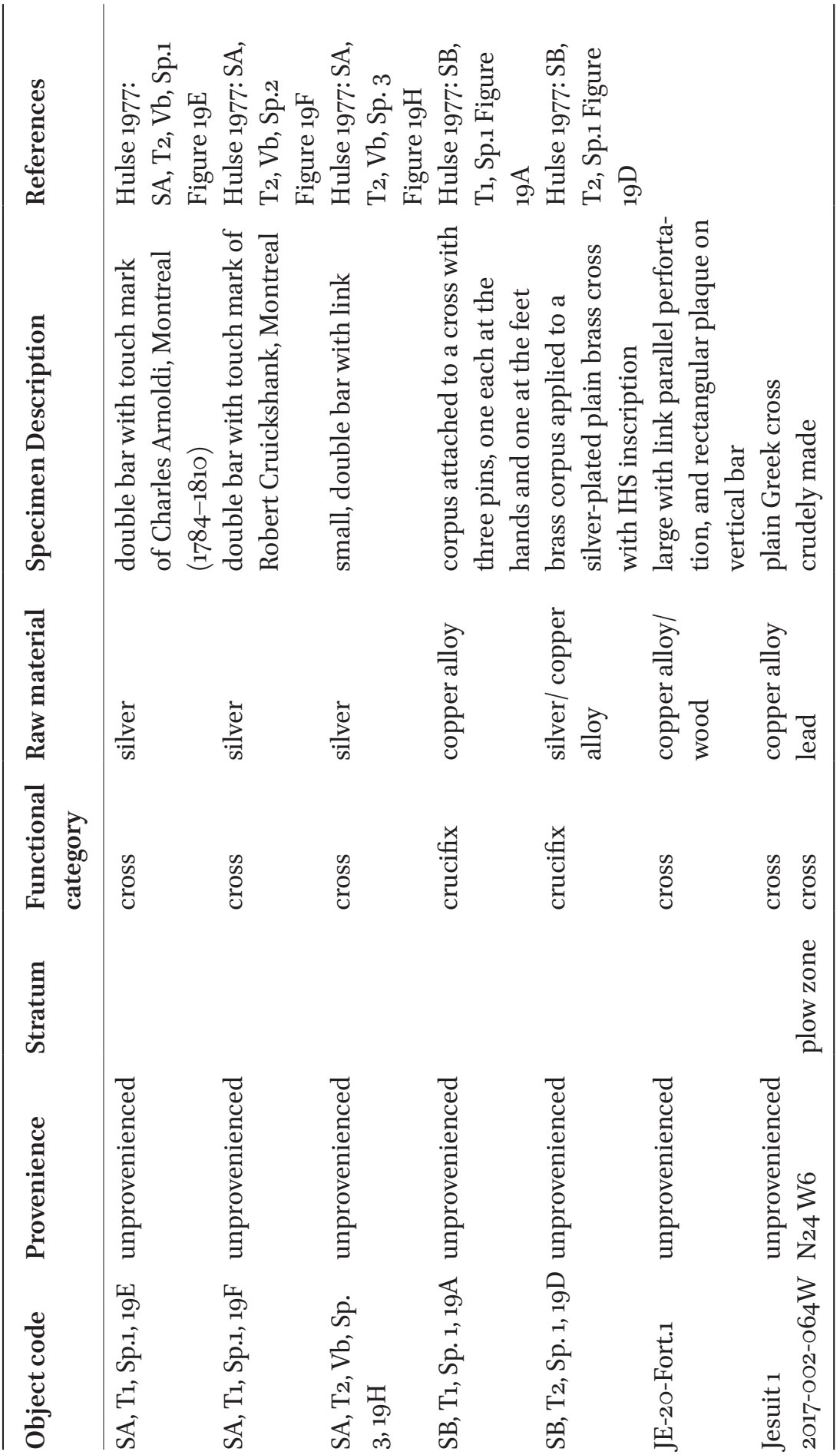




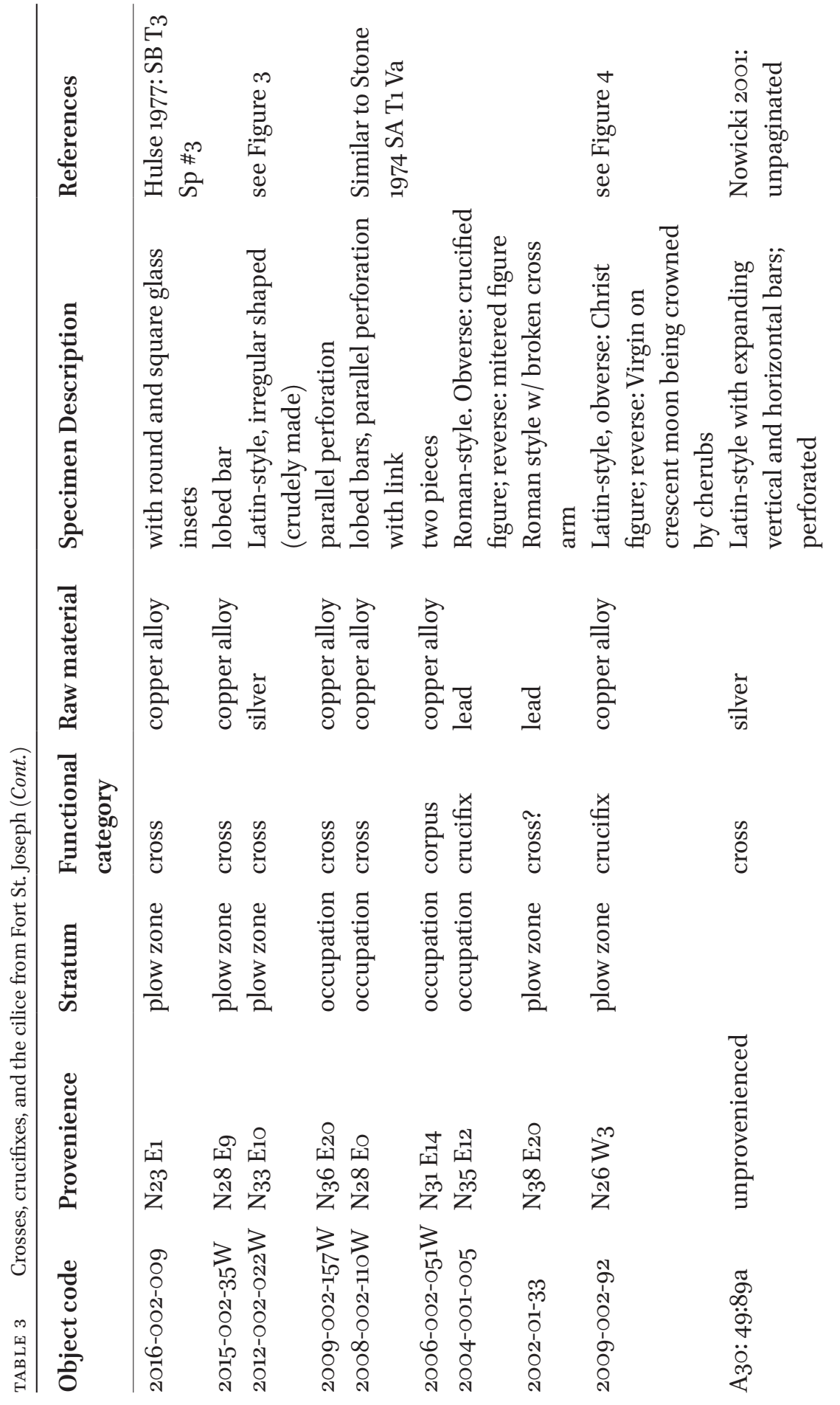




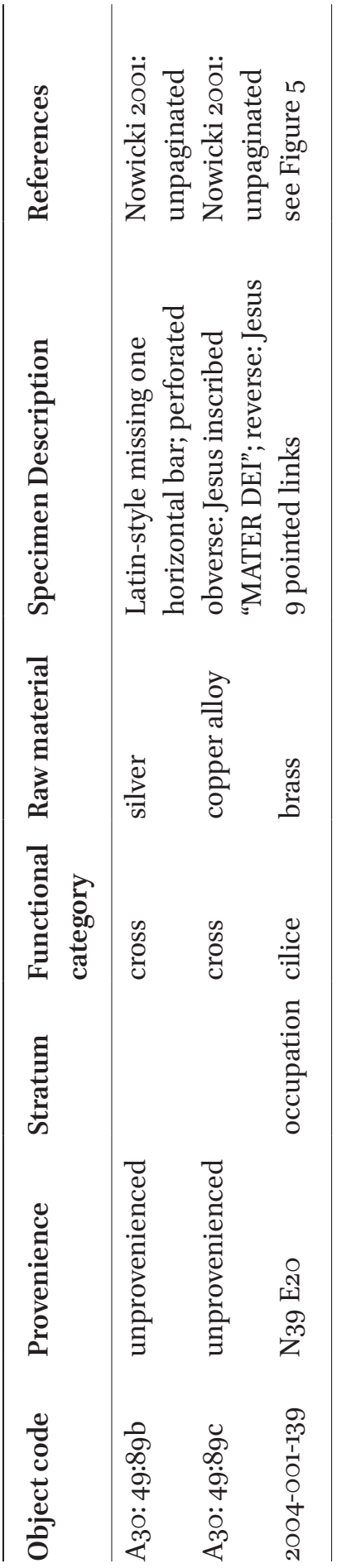




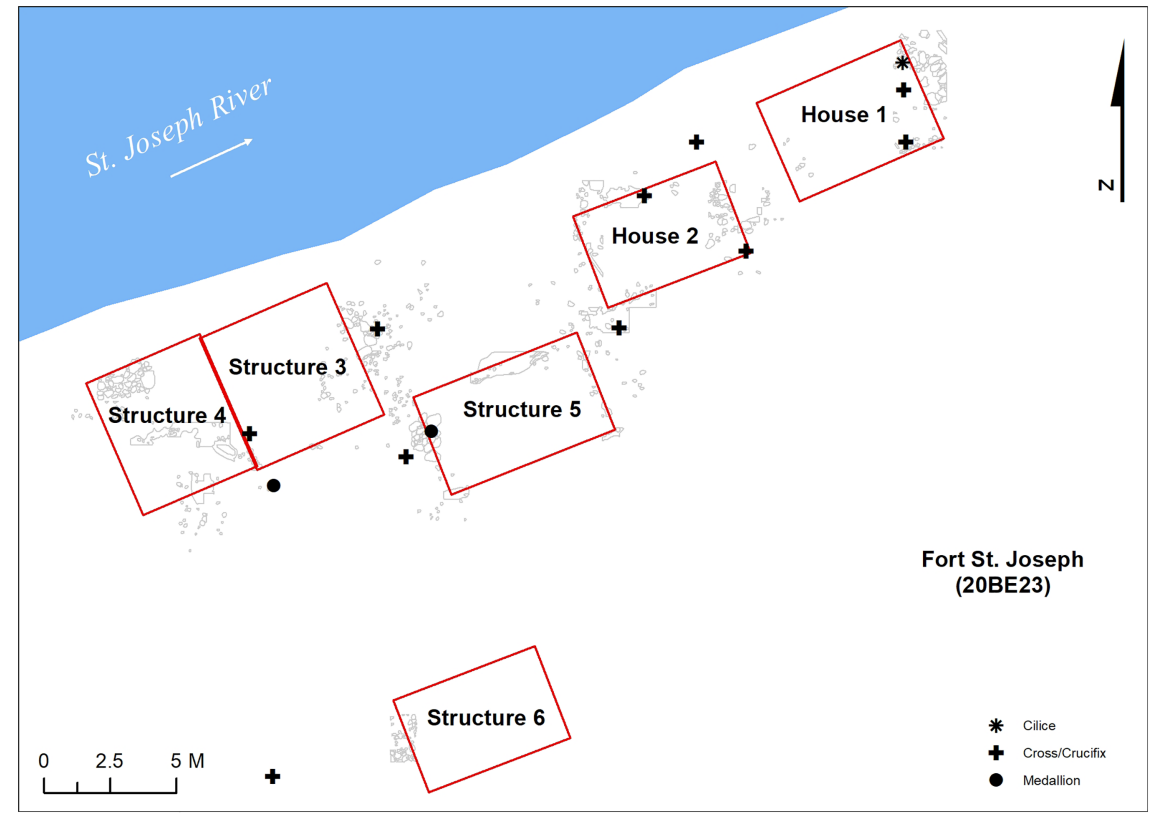

FIGURE 2 Spatial distribution of religious objects at Fort St. Joseph MAP BY JASON GLATZ

Several objects were recovered from the area where the blacksmith may have worked and lived at Fort St. Joseph (Structures 3 and 4), but not in large enough numbers to indicate craft production (Figure 2).

\section{Medallions}

All of the medallions $(\mathrm{n}=12)$ from Fort St. Joseph are made of a copper alloy and depict religious iconography on both the obverse and reverse (Table 2). In his study of religious medals from the sixteenth through eighteenth centuries, Timothy Riordan sought to identify chronologically sensitive attributes including shape, attachment, size, and inscription..$^{45}$ Oval medals (50\%) predominate at Fort St. Joseph. This form is most common at all time periods, decreasing slightly in popularity through time. It is tempting to suggest that these medals are the oldest in the collection, and the round (33\%) and octagonal ones $(17 \%)$ are more recent, though the percentages are consistent with the data that Riordan presents for the eighteenth century. Perpendicular $(50 \%)$ and parallel $(42 \%)$ attachments are almost equally represented; the former

45 Riordan, "To Excite the Devotion of the Catholics," Table 2. Riordan used materials from Fort St. Joseph to compile his frequency data. 
TABLE 4 Forms of religious paraphernalia by raw material in the Fort St. Joseph collection

Form Raw Materials

\begin{tabular}{lccccr}
\hline & Copper alloy & Lead & Silver/Pewter & Mixed & Total \\
\hline Cross & 8 & 4 & 13 & 4 & 29 \\
Crucifix & 5 & 1 & 0 & 1 & 7 \\
Medallion & 12 & 0 & 0 & 0 & 12 \\
Cilice & 1 & 0 & 0 & 0 & 1 \\
\hline
\end{tabular}

are much more common in the eighteenth century. ${ }^{46}$ These tend to co-occur with the oval medals supporting their placement early in the fort occupational sequence.

All of the medals depict religious iconography and would have been useful visual aids for instructing the recently converted. Representations include the crucifixion, the Eucharist, the Benedictine cross, the holy family (Jesus, Mary, Ann), and explicit Jesuit iconography. This includes the Christogram "IHS," St. Francis Xavier, and St. Ignatius, the founder of the Society of Jesus. These latter figures are surrounded, respectively, by the phrases: "S. XAV. soc. IESV I. AP." (St. Francis Xavier, Society of Jesus's first apostle) and "S. I GNATIVs. soc. IESv. F" (St. Ignatius, Society of Jesus's founder) ${ }^{47}$ The inscriptions on all but one of the medals are in Latin; the lone French example commemorates the death and resurrection of Christ. These medals were likely intended both as didactic tools for new converts and as religious reminders to the French Catholics who were devout practitioners.

\section{Crosses and Crucifixes}

Perhaps the most iconic symbol in Catholicism is the cross representing the crucifixion of Christ, a central tenet of Catholic belief. The Latin cross is most common at Fort St. Joseph, though the Greek and double-barred forms also occur (Table 3).$^{48}$ It may be useful to distinguish the cross from the crucifix; the latter includes the body of Christ on the cross itself, whereas the cross alone is often a sufficient representation. Crosses are more common than crucifixes, representing eighty-one percent of the sample. Here we treat them together in our discussion and refer to them as crosses unless otherwise specified.

46 Riordan, "To Excite the Devotion of the Catholics," Table 3.

47 Hulse, "Archaeological Evaluation of Fort St. Joseph," 388.

48 On the variety of crosses see, Deagan, Artifacts of the Spanish Colonies, Figure 4.13. 
Crosses were made of silver, copper alloy, lead, and mixed media (e.g., copper alloy with glass insets; wood covered with copper alloy) (Tables 3 and 4). Copper alloy was a preferred raw material prior to $c .1760$ when silver crosses and crucifixes appear more regularly in the archaeological record. ${ }^{49}$ Silver and copper alloy crosses are equally represented in the collection. The silver crosses likely date to the end of the fort occupation (c.1761-81) when the Jesuits no longer frequented the fort, then under English control. Indeed, two crosses have touch marks of Montreal silversmiths who were active in the late eighteenth and early nineteenth centuries. Even though the French had relinquished control of the fort after 1761 , they continued to occupy it and were allowed to retain and practice their religion by the Quebec Act of 1774 . Alternatively, these crosses had lost their religious meaning and were seen as secular trade goods, as Rinehart suggested for Fort Michilimackinac.

One of the crosses (2012-002-022W) appears to have been cut from a larger piece of silver and was likely made locally (Figure 3). This deliberate attempt to produce a form that replicates a Latin cross (as opposed to some other decorative shape) suggests an intentional effort to create an object with a clear religious meaning.

Unlike the plain silver crosses, cast or stamped copper alloy crosses exhibit more elaborate iconography, typically depicting the figure of Christ in varying degrees of detail. On the reverse of one of the Latin style-crucifixes is a very detailed motif of the Virgin above a crescent moon being crowned by cherubs - a clear portrayal of the assumption of Mary into heaven (Figure 4). Similarly, Riordan illustrates an early seventeenth-century oval medal depicting the annunciation. ${ }^{50}$ We see these as didactic media selected to reinforce messages about important Catholic Scripture and suggest that the Jesuits were using specific iconography to teach theological beliefs. We suspect that the wearers were likely familiar with this theology and the meaning of these symbols.

\section{Discussion}

Devotional artifacts confirm what documentary sources suggest; namely that the Jesuits tended to their flock of recent converts and inculcated religious beliefs through their teachings, aided by material culture. Further support for

49 George Quimby, Indian Culture and European Trade Goods: The Archaeology of the Historic Period in the Western Great Lakes (Madison: University of Wisconsin Press, 1966).

50 Riordan, "To Excite the Devotion of the Catholics," 71, Figure 1. 


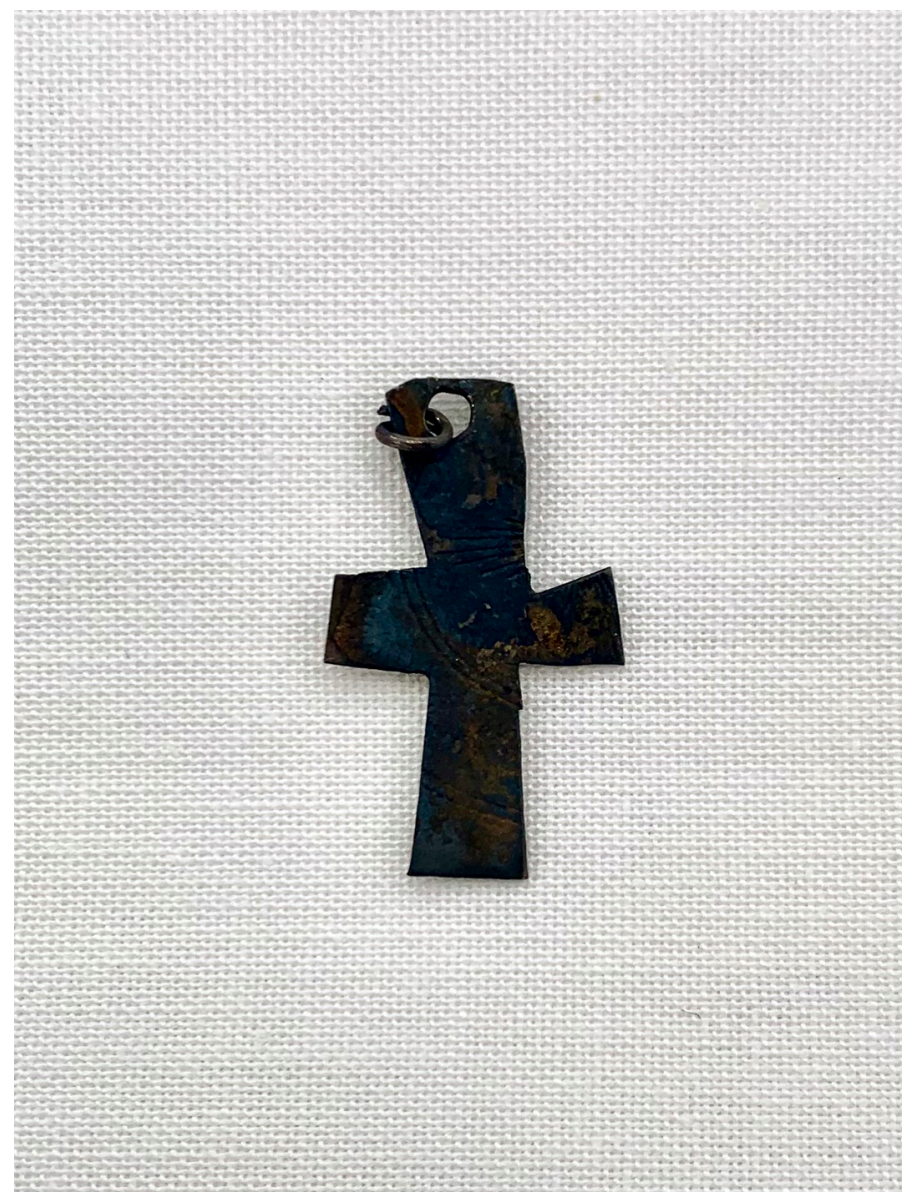

FIGURE 3 Locally produced Latin-style silver cross (accession number 2012-002-022W). Length: $2.4 \mathrm{~cm}$ PHOTO BY ERIKA HARTLEY

this inference is provided by the recovery of a cilice from our excavations. This object of self-mortification, consisting of a series of looped, pointed brass wires, was worn to inflict pain, emulate the suffering of Christ, and attain a state of grace (Figure 5$) \cdot{ }^{51}$ Although we cannot be sure precisely who the wearer of this devotional aid may have been, this ascetical instrument was almost certainly worn in a covert manner as was the common European practice, and not displayed as a visible sign of piety. This suggests that this artifact still retained its religious connotations and was not transformed into a secular object.

51 Brandão and Nassaney, "Suffering for Jesus: Penitential Practices at Fort St. Joseph (Niles, Michigan) during the French Regime," 476-99. 


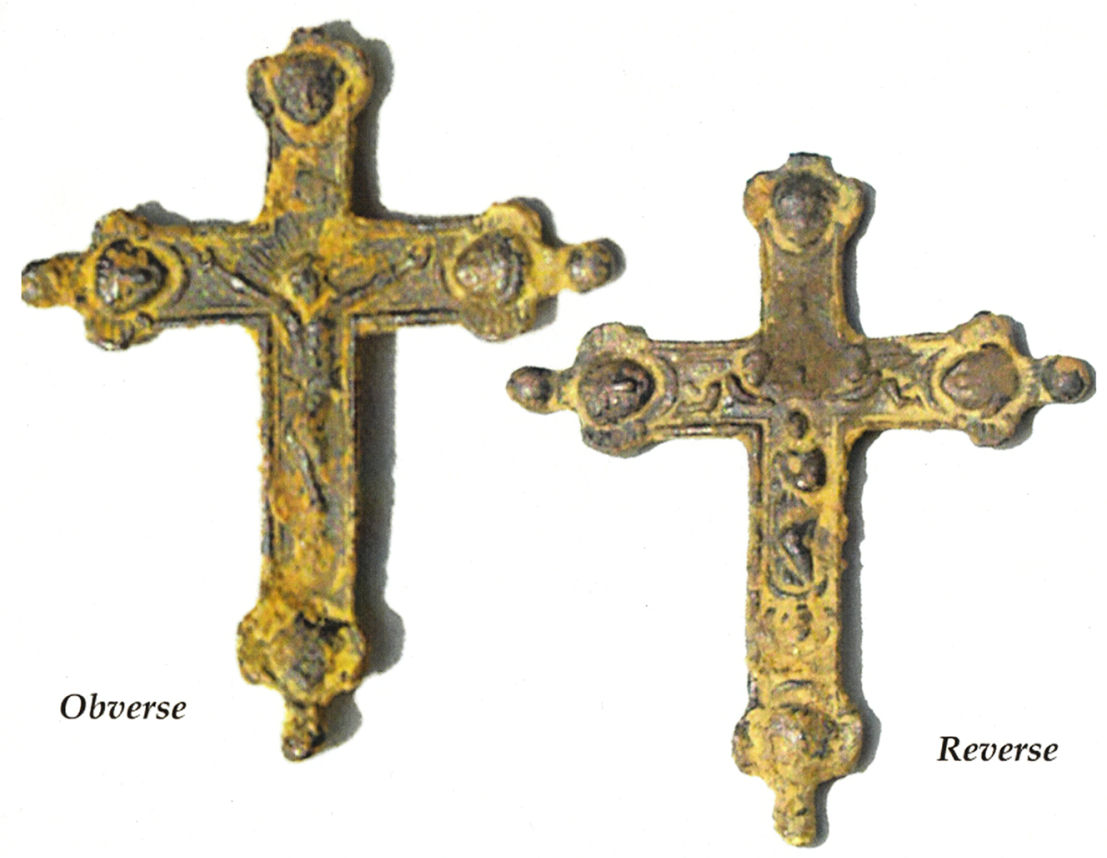

FIGURE 4 The Assumption of the Virgin Mary into heaven as depicted on the reverse of this copper alloy crucifix (accession number 2009-002-92) PHOTO BY JOHN LACKO

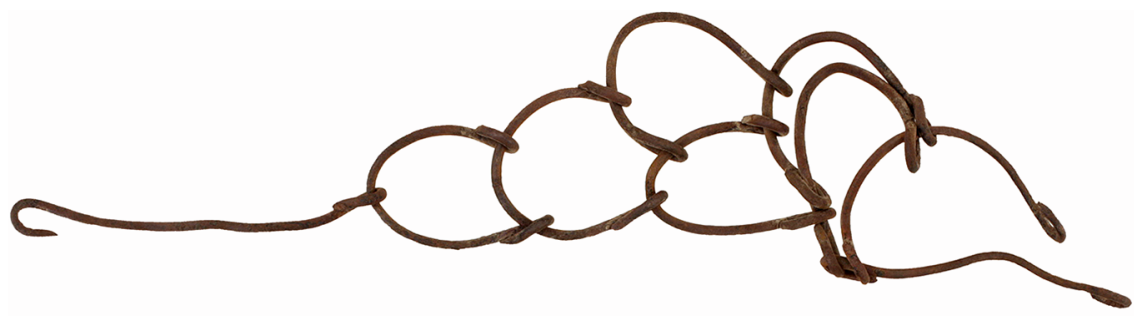

FORT ST. JOSEPH ARCHAEOLOGICAL PROJECT WESTERN MICHIGAN UNIVERSITY

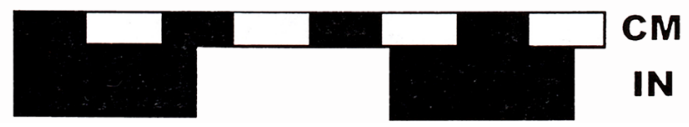

FIGURE 5 Fort St. Joseph cilice (accession number 2004-oo1-139) PHOTO BY JOHN LACKO 
Contextual data exists for all the objects that were recovered from excavations since 1998. Although the sample is small, their provenience allows us to relate them to the site occupants, at least in a general sense. Figure 2 shows the distribution of devotional artifacts and their proximity to a series of buildings identified at the site. Two observations follow. First, the near uniform spatial pattern of religious objects suggests that all households had access to and used these goods. Second, independent data on the size, form, method of construction, and content of these buildings suggest that they were domestic structures occupied by French fur traders and their families, whereas one area (Structures 3 and 4) may have been used by the blacksmith. ${ }^{52}$ Despite the presence of religious artifacts throughout the site, none appear to be associated with a church, chapel, or burial ground, which we have yet to identify. Thus, it appears that French fur traders and their families were generally devout believers who used and lost objects of devotion in domestic spaces.

It is informative to compare the types of religious paraphernalia from Fort St. Joseph with those recovered from Fort Michilimackinac, a regional distribution center at the Straits of Mackinac where the Jesuits also resided and conducted their mission. Fort Michilimackinac was occupied by the French beginning in 1715. It supported a church adjacent to a habitation structure occupied by priests throughout the French regime. As at Fort St. Joseph, religious artifacts associated with public and private spaces have been recovered from more than sixty years of archaeological excavations. ${ }^{53}$ Although Michilimackinac was a somewhat larger site, the numbers of religious objects recovered from each site are comparable (Table 5). Nearly twice as many medallions have been recovered from Michilimackinac, perhaps evidence of their production at the site. Differences in the frequency of crosses and crucifixes is particularly notable. While there are significantly more crucifixes at Michilimackinac, Fort St. Joseph has considerably more crosses. If the crosses, many of which were made of silver, do indeed post-date 1761 when priests seldom frequented the site, then perhaps they were intended for trade. In his study of the medallions and crucifixes from Michilimackinac, Rinehart opined that by the eighteenth-century medallions and crucifixes were fulfilling different functions. Whereas medallions retained their religious significance and were personal possessions of the devout, crosses had become more secular in

$52 \quad$ Erika Hartley and Michael S. Nassaney, "Architectural Remains at Fort St. Joseph," in Michael S. Nassaney, ed., Fort St. Joseph Revealed: The Historical Archaeology of a Fur Trading Post (Gainesville: University Press of Florida, 2019), 79-100.

53 Evans, "Artifacts of Religious Devotion at Michilimackinac"; Rinehart, "Crucifixes and Medallions from Michilimackinac." 
TABLE 5 Frequency of religious paraphernalia from Fort Michilimackinac and Fort St. Joseph

\begin{tabular}{lcc}
\hline Form & Fort Michilimackinac* $^{*}$ & Fort St. Joseph \\
\hline Metal medallions & 23 & 12 \\
Clay medallions & 1 & 0 \\
Crucifixes & 26 & 7 \\
Corpi (detached from & 7 & 1 \\
crucifixes) & & \\
Crosses & 6 & 29 \\
Total & 63 & 49 \\
\hline
\end{tabular}

*Data provided by Lynn Evans.

usage and perhaps lost their religious meaning. This may have been the case with the plain copper alloy and silver crosses that dominate at Fort St. Joseph. These crosses may have been distributed by someone other than the priests, for whom the depiction of the crucified Christ would have been central to their message (Table 3).

\section{Summary and Conclusions}

The documentary and archaeological evidence, when used in tandem, suggest that the Jesuits at Fort St. Joseph enjoyed some degree of success in attending to the spiritual needs of the French and their Native allies, even if the results did not match idealistic aspirations. Still, the Jesuits were, by the eighteenth century, clear-eyed in assessing the task before them and their achievements. Charlevoix noted that the Miami and Potawatomi at the St. Joseph Mission were, "for the most part, Christian, but they have been a long time without pastors and the missionary sent to them a little while ago, will have not a little to do to get them back into the exercise of their religion." ${ }^{54} \mathrm{He}$ might have made the same case for the French denizens of the fort, as they had been in the same circumstances. That he did not say as much suggests that he had different standards or expectations for French and Indians and/or that his label of "Christian" for the Indians was too loosely applied. The situation may have been exacerbated after 1761, when fewer priests were available and silver artifacts desired by Native peoples became more readily available. Still, the view of early missionaries and their supporters that change would be sweeping and

54 Charlevoix, Histoire et description, 3:312. 
quick had long succumbed to reality: people change slowly, and teaching a new religion would be a life-long process, as it would be to maintain people in a faith. Rituals for even the devout, such as masses, are, after all, performed at regular intervals to inculcate understanding and practice.

The question of "sincerity" of conversion is not new. In a secular age it is easy to dismiss the appeal of religion but, as Tracy Neal Leavelle cautions, to do so is "to downplay or disparage" Indians' personal choices, and "to devalue or even invalidate the frequently profound experiences of Native people." 55 In the seventeenth and eighteenth centuries, the area known as New France was inhabited by people who believed in a world shaped, if not controlled, by forces outside their control. That was as true for the French as for the Indians. Nor was a French understanding of Catholicism perfect, and the line between faith, superstition, and magic was often blurred. As Peter Moogk has written, the "colonists' universe was rational in the sense that every event had a cause and justification, but the cause might be supernatural and the justification religious." ${ }^{56}$ Nor were Catholics above practicing their religion out of fear of retribution from their god, or of confusing religious objects as amulets with the power to protect them rather than as reminders of their faith. ${ }^{57}$ To apply some standard of purity or to seek "proof" of divine belief in the minds of Indiansbeliefs and practices that were assumed for French Catholics-is unrealistic at best, and misguided at the least. Conversion, as Leavelle notes, is a process informed by, among other things, one's own culture. ${ }^{58}$ Indian converts were all somewhere along that continuum of change and converted for a variety of reasons. Short of some anachronistic and amateurish psychoanalysis of the long dead, one is unlikely to find "proof" of sincerity of conversion or the reasons for it. We argue that what can be done is to evaluate "practices" as expressed in the historical and archaeological records, apply the same criteria to those practices as they pertain to Indians and French, and hazard a conclusion about what they reveal. And, to be sure, there were some prospective converts who outright rejected the invitation for eternal salvation. Some Natives viewed Catholic teaching with suspicion. Native religion had served them well for millennia and many were not apt to adopt foreign beliefs lest they be shown some clear benefits to Catholicism.

55 Tracy Neal Leavelle, The Catholic Calumet: Colonial Conversions in French and Indian North America (Philadelphia: University of Pennsylvania Press, 2012), 203.

$5^{6}$ Peter Moogk, La Nouvelle-France: The Making of French Canada; A Cultural History (Lansing: Michigan State University Press, 2000), 241.

57 Moogk, Nouvelle-France, 235, 236, 238.

$5^{8}$ Leavelle, Catholic Calumet, 8-10, 135-44, 152, 202-3. 
Nevertheless, these data suggest that Jesuits at the St. Joseph mission baptized children and adults, performed marriages, administered last rites to dying devotees, and used devotional artifacts for practical and didactic purposes. The denizens of the area also visibly displayed (and sometimes hid but still wore) religious paraphernalia as a testimony to the sincerity of their beliefs. The Jesuits could claim to their superiors and benefactors that they were indeed doing God's work in New France and to some real effect, even if it fell short of their once lofty goals. But falling short of divine expectations is, the faithful must acknowledge, to be human. 